\title{
Analisis Bukti Digital Trim Enable SSD NVME Menggunakan Metode Static Forensics
}

\section{(Analysis of Digital Evidence Trim Enable on SSD NVME Using Static Forensics Method)}

\author{
Imam Riadi ${ }^{1}$, Sunardi $^{2}$, Abdul Hadi ${ }^{3}$ \\ ${ }^{1}$ Program Studi Sistem Informasi, Universitas Ahmad Dahlan \\ ${ }^{2}$ Program Studi Teknik Elektro, Universitas Ahmad Dahlan \\ ${ }^{3}$ Program Studi Teknik Informatika, Universitas Ahmad Dahlan \\ 1imam.riadieis.uad.ac.id \\ ${ }^{2}$ sunardi@mti.uad.ac.id \\ 3 abdul1808048032@webmail.uad.ac.id
}

\begin{abstract}
Abstrak - Bukti digital sangat penting dalam pembuktian kasus kejahatan komputer yang melibatkan perangkat penyimpanan. Salah satu media penyimpanan terkini saat ini adalah SSD NVMe, secara default sistem operasi Windows 10 terpasang TRIM dengan mode enable, fungsi TRIM mengoptimalkan kinerja kecepatan SSD NVMe dengan cara menghapus otomatis data lama pada sebuah sektor sebelum ditempatkan data baru sehingga menjadi tantangan investigator untuk mengembalikan bukti digital. Tujuan penelitian melakukan analisis bukti digital yang terhapus dengan metode penghapusan permanen dengan cara shift delete dan delete, delete recycle bin menggunakan tools forensics yang berbeda untuk mengembalikan bukti digital pada SSD NVMe TRIM enable. Metode yang digunakan static forensics sedangkan tools yang digunakan FTK Imager, Autopsy dan Recuva. Hasil analisis TRIM enable metode penghapusan shift delete tidak ditemukan bukti digital yang sesuai nilai hash dengan bukti digital asli. Sedangkan metode penghapusan delete, delete recycle bin bukti digital dapat dikembalikan dengan prosentase keberhasilan menggunakan tool Autopsy sebesar $90 \%$ dan $10 \%$ nilai hash bukti digital tidak valid, sedangkan tool Recuva $80 \%$ bukti digital berhasil dikembalikan dan $20 \%$ tidak berhasil dikembalikan, dapat disimpulkan hasil recovery penghapusan delete, delete recycle bin pada SSD NVME TRIM enable dapat dijadikan bukti digital yang sah menurut hukum.
\end{abstract}

Kata-kata kunci: Forensika digital, Restorasi, Hapus Permanen, NVMe, NIST

Abstract - Digital evidence is very important in proving computer crime cases involving storage devices. One of the latest storage media is the SSD NVMe, by default the Windows 10 operating system is installed TRIM with enable mode, the TRIM function optimizes the SSD NVMe speed performance by automatically removing old data in a sector before new data is placed so that it becomes a challenge for investigators to return digital evidence. The purpose of the study is to analyze digital evidence that is erased with the method of permanent erasure by means of shift delete and delete, delete recycle bin using different forensics tools to restore digital evidence on SSD NVMe TRIM enable. The method used is static forensics while the tools used are FTK Imager, Autopsy, Recuva. The results of the TRIM enable the deletion shift delete there is not found digital evidence that matches the hash value with original digital evidence. While the method of deletion delete, delete recycle bin digital evidence can be returned with the percentage of success using the Autopsy tool of $90 \%$ and $10 \%$ hash value of invalid digital evidence, while the Recuva tool $80 \%$ of digital evidence has been returned successfully and $20 \%$ has not been returned successfully, it can be concluded that the recovery deletion delete, delete recycle bin on the SSD NVMe TRIM enable can be used as legal digital evidence according to law.

Keywords : Digital Forensics, Restoration, Delete Permanently, NVMe, NIST

\section{PENDAHULUAN}

Dinamika kejahatan cyber diberbagai negara sangat beragam yang melibatkan barang bukti elektronik maupun digital, sebagian barang bukti elektronik adalah komputer [1]. Penggunaan komputer sebagai alat kejahatan dapat berupa pengambilan data penting secara ilegal, manipulasi data, membocorkan data penting dan penyalahgunaan perangkat komputer baik hardware maupun software untuk akses tidak sah [2].

Perkembangan teknologi media penyimpanan saat ini dituntut cepat dalam membaca dan menulis data menyesuaikan perkembangan perangkat keras yang 
lainnya seperti processor dan Random Access Memory (RAM). Media penyimpanan Solid State Drive Nonvolatile Memory Express (SSD NVMe) memiliki perbedaan bentuk dan interace dengan SSD SATA [3], berikut perbedaan fisik SSD NVMe pada Gambar 1 (a) dan SSD SATA Gambar 1 (b).

SSD NVMe memiliki fitur TRIM secara default terpasang pada sistem operasi Windows dengan mode enable [4], fitur ini secara otomatis menghapus data lama pada sektor penyimpanan sebelum ditempatkan data baru sehingga SSD NVMe dapat membaca data secara optimal [5] [6].

Kontradiksi penggunaan fitur TRIM pada SSD NVMe dari sisi digital forensics adalah fungsi TRIM memiliki efek negatif pada analisis bukti digital forensics khususnya pada pengembalian atau restorasi bukti digital [7]. Barang bukti digital yang dihapus tidak dijamin dapat dikembalikan, karena controller pada SSD NVMe TRIM enable berfungsi untuk menghapus garbage collection [8] [9].

Berdasarkan studi literatur dari penelitian terdahulu sebagai pendukung penelitian ini, ditemukan penelitian dengan tema sejenis peneliti membandingkan tools forensik untuk analisis dan eksaminasi SSD SATA (Controller AHCI) dengan mode TRIM, penelitian menghasilkan mekanisme TRIM pada SSD SATA saat diaktifkan menimbulkan kendala dalam penyelidikan digital forensics. Ketika diaktifkan mekanisme TRIM memiliki pengaruh pada sistem operasi. Sistem operasi yang digunakan adalah windows 7 dengan file sistem NTFS, metode akuisisi yang digunakan static forensics dan tool yang digunakan adalah Forensic Toolkit (FTK) dan Sleuth Kit Autopsy [10]. Peneliti lain menganalisis perbandingan fitur TRIM enable dan TRIM disable pada SSD NVMe, metode penghapusan permanen hanya menggunakan shift delete, tools yang digunakan RecoverMyFile dan Autopsy. Hasil yang didapat saat TRIM enable aktif bukti digital tidak dapat dikembalikan sedangkan TRIM disable 92\% dapat dikembalikan dengan baik [8]. Peneliti lain juga melakukan perbandingan fitur TRIM pada SSD SATA yang berjalan pada sistem operasi yang berbeda, pada konektor kabel yang berbeda dan pada file sistem berbeda. Tools yang digunakan untuk mengembalikan artefak adalah Recuva dengan meteode penghapusan shift delete, hasil penelitian menunjukkan hasil yang berbeda saat fitur TRIM diaktifkan dan dinon-aktifkan [11]. Peneliti lain juga melakukan analisis bukti digital pada SSD SATA dengan metode live forensics menggunakan perangkat lunak Grr Rapid Response (cliet-server), metode penghapusan dengan delete biasa. Bukti digital yang dapat dikembalikan berupa file dokumen, hasil validitas pada bukti digital tersebut memiliki nilai hash yang sama dari dua algoritma validitas bukti digital yang diimplementasikan MD5 dan SHA-1 [12].

Tujuan penelitian melakukan analisis bukti digital yang terhapus (lost data) dengan metode penghapusan permanen dengan cara shift delete dan delete, delete recycle bin menggunakan tools forensics yang berbeda untuk mengembalikan bukti digital pada SSD NVMe TRIM enable. Penelitian ini menerapkan langkah kerja (framework) National Institute of Standards and Technology (NIST) untuk mendapatkan bukti digital yang valid dan dapat dipertanggungjawabkan menurut hukum. Penulis melakukan penelitian ini menggunakan sistem operasi windows 10 Build 1803 dengan menerapkan metode static forensics.

\section{METODE}

Metodologi menjelaskan urutan langkah-langkah yang dibuat secara sistematis dan dapat dijadikan pedoman yang jelas dalam menyelesaikan permasalahan, membuat analisis terhadap hasil penelitian. Adapun tahapan penelitian dimulai dari studi literatur mengumpulkan penelitian terdahulu dari berbagai sumber, menyiapkan environment berupa alat simulasi penelitian, membangun simulasi kasus yaitu membuat rancangan studi kasus yang tidak nyata, melakukan pemeriksaan dan analisis kasus yaitu melakukan implementasi simulasi kasus sesuai metode static forensics dan terakhir memberikan diskusi dan kesimpulan. Tahapan ini dapat dilihat pada Gambar 2.

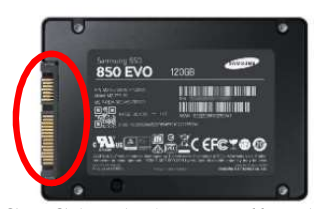

(b) SSD SATA (controller AHCI)

(a) SSD NVMe M.2 (controller NVMe)

Gambar 1. Perbedaan fisik SSD NVMe dan SSD SATA 


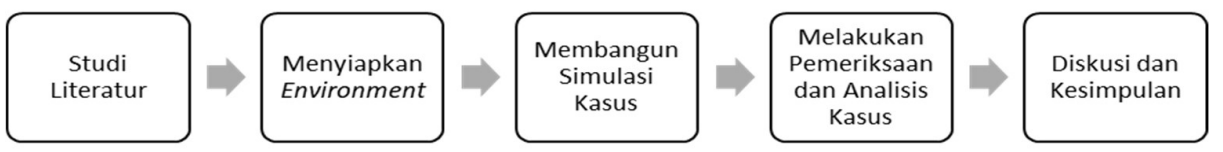

Gambar 2. Metodologi Penelitian

Tahapan penelitian menggunakan metode static forensics yaitu metode konvensional penanganan barang bukti elektronik berupa komputer dalam keadaan mati [13]. Pemilihan model langkah kerja forensik harus memenuhi individuality, repeatability, reliability, performance, testability, scalability, dan quality standards [14]. Pada tahapan analisis peneliti menggunakan framework National Institute of Standards and Technology (NIST) [15]. Barang bukti digital diambil dari salinan image yang diambil dari salinan media penyimpanan fisik [16]. Framework NIST mengarahkan langkah-langkah dan alur penelitan secara sistematis sehingga dapat menyelesaikan masalah penelitian sesuai prosedur forensika digital. Menggunakan metode dan framework yang tepat memiliki keberhasilan hampir $100 \%$ untuk mengumpulkan barang bukti digital forensics [17][18]. Berikut framework NIST pada Gambar 3.

Penjelasan tahapan framework NIST sebagai berikut:

A. Collection: Melakukan identifikasi barang bukti fisik, pelabelan, record, retrieve dari sumber data yang relevan dan akuisisi image dengan mengaktifkan write blocker [19].
B. Examination: Melakukan pemilahan dan pemeriksaan bukti digital.

C. Analysis: Melakukan pemeriksaan bukti digital secara teknis dan legal untuk mendapatkan informasi berguna yang dapat dipertanggungjawabkan secara ilmiah dan secara hukum.

D. Reporting: Pelaporan dilakukan setelah diperoleh barang bukti digital dari proses pemeriksaan data analisis yang meliputi penggambaran tindakan yang dilakukan.

Alat dan bahan yang dibutuhkan pada penelitian ini adalah Desktop Mini A300, 1 pes SSD NVMe Samsung 970 evo kapasitas 250GB, Notebook Thinkpad yoga 14 untuk analisis, Converter NVMe to USB, Windows 10 Pro Build 1803, FTK Imager, Autopsy versi 4.13 dan Recuva v.1.53 dan satu file bukti digital masing-masing mempunyai ekstensi exe .pdf .docx .xlsx .ppt .jpg .bmp .png .mp3, dan .mp4 total sepuluh file bukti digital persesi, berikut bukti digital asli dan hash pada Tabel 1.

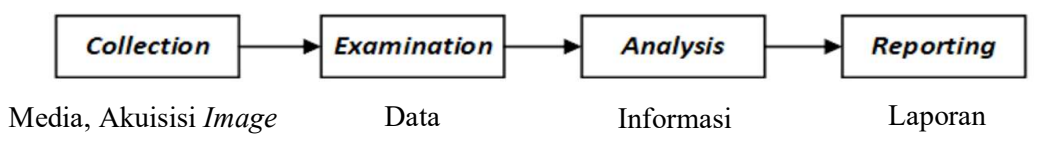

Gambar 3. Framework NIST

TABEL I

HASH DAN LETAK ALOKASI BUKTI DIGITAL ASLI

\begin{tabular}{|c|c|c|}
\hline Tipe File & Nama File dan letak & Hash MD5 \\
\hline \multirow[t]{2}{*}{ Aplikasi } & D: $\backslash$ Sesi 1 exe & cfa3b524adf84a36be619992f9d632ff \\
\hline & E: $\mid$ Sesi 2 exe & $1 \mathrm{bc} 6927 \mathrm{cce} 8627 \mathrm{f} 860 \mathrm{ae} 51684 \mathrm{~b} 32 \mathrm{ce} 5 \mathrm{~d}$ \\
\hline \multirow[t]{8}{*}{ Dokumen } & $\mathrm{D}:$ Sesi 1 pdf & $00437830 b b 34 f 5 b 20 c 285 d 2 f 9117 d 4 e 3$ \\
\hline & E: Sesi 2 pdf & 0a569b127c7de6bea02cf6e87e41c5f2 \\
\hline & $\mathrm{D}:$ Sesi 1 docx & $4 \mathrm{fe} 577 \mathrm{c} 986 \mathrm{bcdb} 7144 \mathrm{c} 0474 \mathrm{~d} 75 \mathrm{e} 44 \mathrm{ed} 9$ \\
\hline & E: ISesi 2 docx & aa125f3e35214c72e3a87a11e3d4903f \\
\hline & $\mathrm{D}:$ Sesi $1 \mathrm{pptx}$ & 159f3b6c92959e4cc90242fcc4dbfe 92 \\
\hline & E: ISesi 2 pptx & $3352425 \mathrm{c} 3 \mathrm{dd} 400$ faca 160 feeeaf 50210 \\
\hline & $\mathrm{D}: \mid$ Sesi 1 xlsx & $53 \mathrm{dcf} 316 \mathrm{ddf} 8 \mathrm{c} 734 \mathrm{fccfb} 760 \mathrm{fbcd} 19 \mathrm{~d} 1$ \\
\hline & E: ISesi 2 xlsx & 77ac2f423a09ef051100e4fe411f9279 \\
\hline \multirow[t]{6}{*}{ Gambar } & D: $\backslash$ Sesi 1 jpg & $6288 \mathrm{e} 8449 \mathrm{~d} 39193 \mathrm{~d} 9 \mathrm{e} 38387 \mathrm{~d} 03178 \mathrm{e} 5 \mathrm{a}$ \\
\hline & $\mathrm{E}: \mathrm{Sesi} 2 \mathrm{jpg}$ & $400277 \mathrm{f} 9 \mathrm{a} 8290 \mathrm{c} 47 \mathrm{def} 497 \mathrm{cfa} 8 \mathrm{ee} 382 \mathrm{c}$ \\
\hline & $\mathrm{D}:$ Sesi $1 \mathrm{bmp}$ & ce306ff $88 f 3 f 458 \mathrm{c} 2 \mathrm{~d} 873605 \mathrm{e} 6570 \mathrm{bc} 9$ \\
\hline & E: Sesi 2 bmp & e86e99e7b0c11c99aaa3a5f14df45ec5 \\
\hline & $\mathrm{D}:$ :Sesi 1 png & c4f5d804b5d04b8bdd0935e5bb6f4a37 \\
\hline & E: Sesi 2 png & 90859f5a69ebca4f7d3d0ff21dd1bb97 \\
\hline \multirow[t]{2}{*}{ Musik } & D: $\backslash$ Sesi $1 \mathrm{mp} 3$ & e1885b2a3bd569c94b40a1c75a0c2f91 \\
\hline & E: Sesi 2 mp3 & 3c7ebc8bf7b1874f57d22a3d40ab5fe9 \\
\hline \multirow[t]{2}{*}{ Video } & $\mathrm{E}: \mathrm{Sesi} 1 \mathrm{mp} 4$ & a099b99e78725f9f21cf3e79dee3d963 \\
\hline & E:ISesi $2 \mathrm{mp} 4$ & d1fc59d463e3e144ed43435396f5f348 \\
\hline
\end{tabular}


Berdasar Tabel 1 untuk mempermudah eksaminasi pada penelitian, penamaan file barang bukti dibagi dua jenis prefix yang membedakan antara sesi dengan sesi yang lain yaitu "Sesi 1 jenis-ekstensi" dan "Sesi 2 jenis-ekstensi ", peletakan bukti digital sesi pertama pada drive $\mathrm{D}$ dan sesi kedua pada drive E. Nilai hash MD5 pada Tabel 1 berbeda antara bukti digital yang satu dengan yang lain karena nilai hash mempunyai nilai unik [20].

Kasus kejahatan komputer dan bukti digital yang digunakan pada penelitian ini tidak didapat dari kejadian nyata, melainkan diperoleh dari hasil skenario kasus tindak kejahatan komputer yang melibatkan media penyimpanan SSD NVMe sesuai dengan Gambar 4.

Kasus yang diskenariokan pada penelitian ini adalah kasus data forgery dan lost data, investigator menemukan barang bukti komputer beserta media penyimpanannya. Skenario penelitian ini dibagi menjadi dua sesi, sesi yang pertama metode penghapusan shift delete dan sesi kedua dengan delete, delete recycle bin. Tahapan implementasi skenario penelitian sesuai Gambar 5.

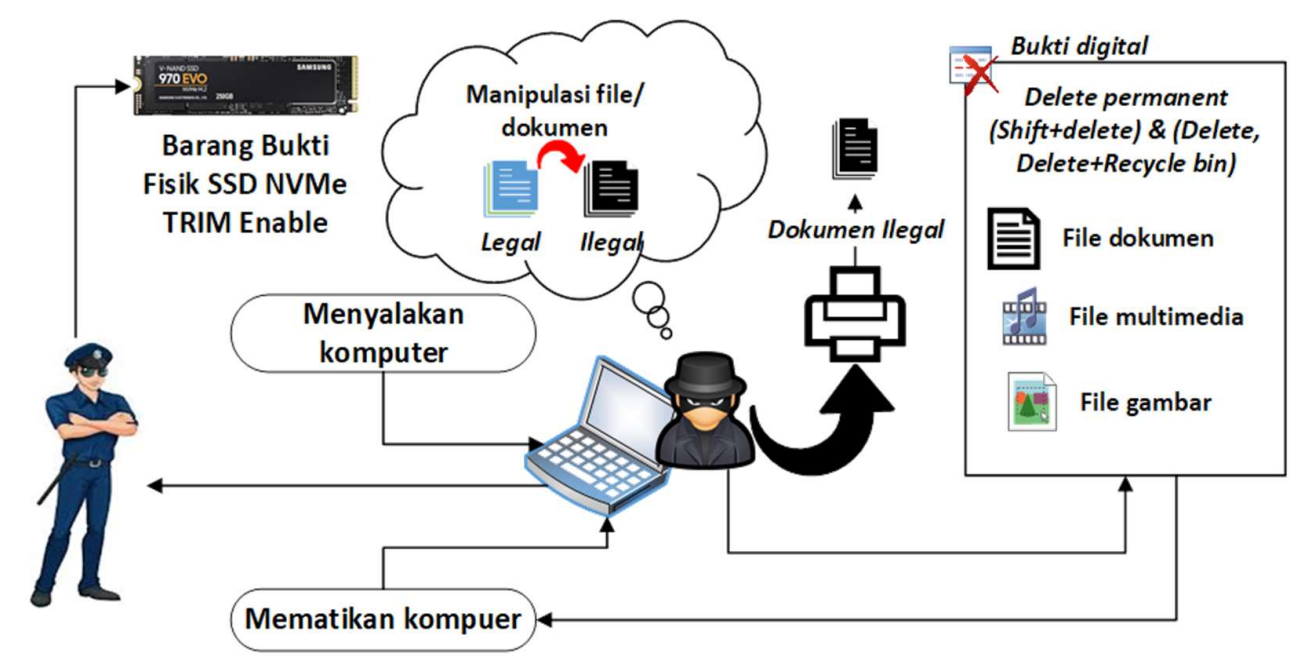

Gambar 4. Skenario kejahatan komputer

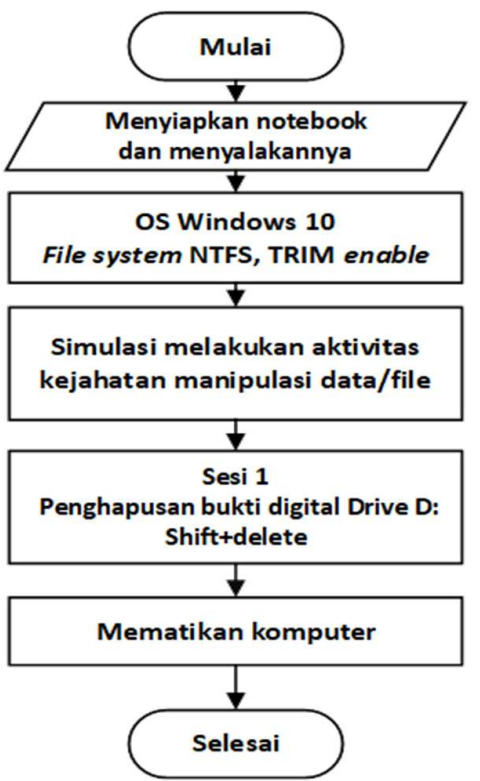

(a) Sesi 1

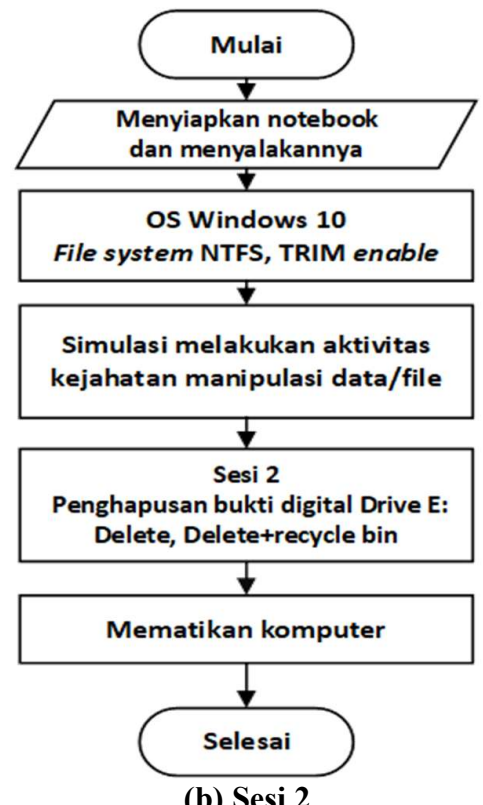

(b) Sesi 2

Gambar 5. Implementasi metode penghapusan bukti digital 
Flowchart pada Gambar 5 menjelaskan tahapan kejahatan penghapusan bukti digital terjadi. Notebook yang dipakai oleh pelaku kejahatan mempunyai sistem operasi Windows 10 dengan media penyimpanan SSD NVMe dengan fitur TRIM enable, Gambar 5 (a) sesi pertama pelaku kejahatan menyimpan dokumen di drive $\mathrm{D}$, sedangkan pada Gambar 5 (b) sesi kedua disimpan di drive E, sesuai pada Gambar 4 pelaku melakukan manipulasi data dan menghapus data asli (lost data). Sesi pertama metode penghapusan menggunakan shift delete, sesi kedua delete, delete recycle bin. Setelah itu pelaku mematikan komputer sesuai prosedur.

Adapun tahapan penelitian yang dilalui pada penelitian ini dirangkum menjadi pada tiga tahap dari framework NIST dan ditambah satu tahapan yaitu skenario dan implemantasi sehingga menjadi empat tahapan utama seperti pada flowchart pada Gambar 6 [16].

\section{HASIL DAN PEMBAHASAN}

\section{A. Skenario dan Implemantasi}

Kasus kejahatan pada penelitian ini berdasar pada skenario kasus pada Gambar 4. Skenario kejahatan pada penelitian ini berupa manipulasi data (forgery data) dan menghapus data asli (lost data). Pelaku kejahatan mencetak data palsu untuk dijadikan laporan fiktif, investigator menemukan barang bukti fisik berupa laptop dan mengambil media penyimpanan berupa SSD NVMe sebagai barang bukti elektronik.

Implementasi penghapusan bukti digital yang dilakukan oleh pelaku kejahatan seperti pada Gambar 6 . Sistem operasi yang digunakan Windows 10 dengan TRIM enable, untuk pengecekan fungsi TRIM enable berjalan pada sistem operasi dilakukan uji coba dengan menggunakan CMD pada windows dan memasukkan perintah "fsutil behavior set disabledeletenotify 0" seperti pada Gambar 7 [21].

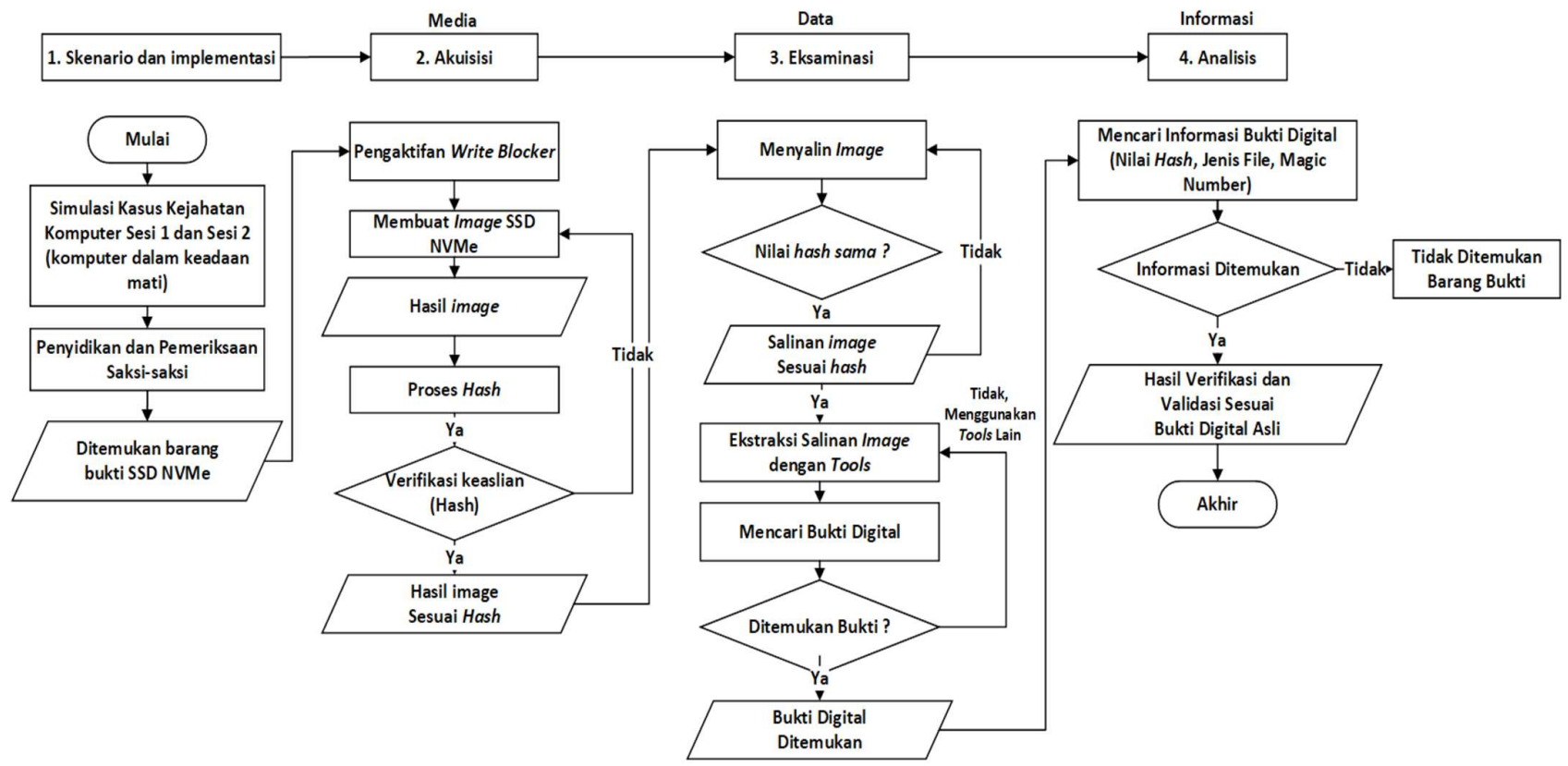

Gambar 6. Empat tahapan utama penelitian

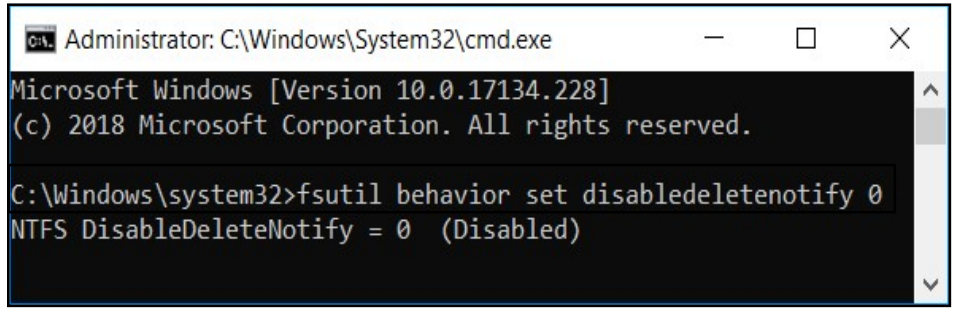

Gambar 7. Perintah TRIM enable di CMD 
Pelaku kejahatan melakukan aksinya dengan memanipulasi data dan menghapus barang bukti sesuai sesi pertama dengan metode penghapusan shift delete pada drive D untuk menghilangkan jejak bukti digital dan mematikan komputer sesuai prosedur, penghapusan shift delete seperti pada Gambar 8 (a). Pelaku kejahatan juga melakukan manipulasi data dan menghapus bukti digital sesuai sesi kedua dengan metode penghapusan delete, delete recycle bin pada drive $\mathrm{E}$ untuk menghilangkan bukti digital seperti pada Gambar 8 (b), setelah menghapus bukti digital pelaku kejahatan mematikan komputer sesuai prosedur.

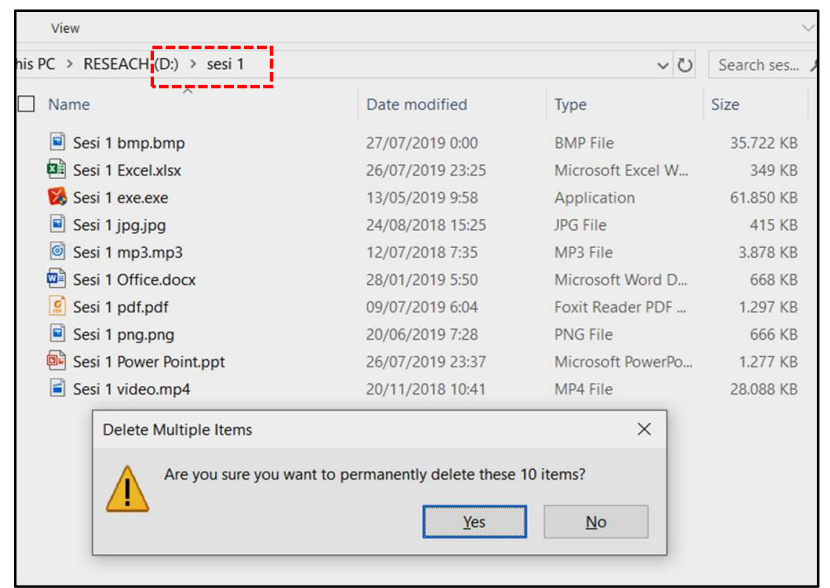

(a) Sesi 1 shift delete drive $\mathrm{D}$ :

\section{B. Akuisisi}

Sebelum melakukan proses akuisisi pada penelitian ini, pencegahan perubahan struktur data yang ada didalam media penyimpan dilakukan dengan pengaktifan write blocker menggunakan tool Safe Block, jika terjadi perubahan struktur data pada media penyimpanan akan merusak nilai hash pada bukti digital. Tampilan konfigurasi write block pada tool Safe Block seperti pada Gambar 9.

Proses ekstraksi bukti digital tidak secara langsung melalui media penyimpanan SSD NVMe namun dibuat image menggunakan teknik akuisisi bit-by-bit-image menggunakan tool FTK Imager berikut Gambar 10 hasil proses pembuatan image.

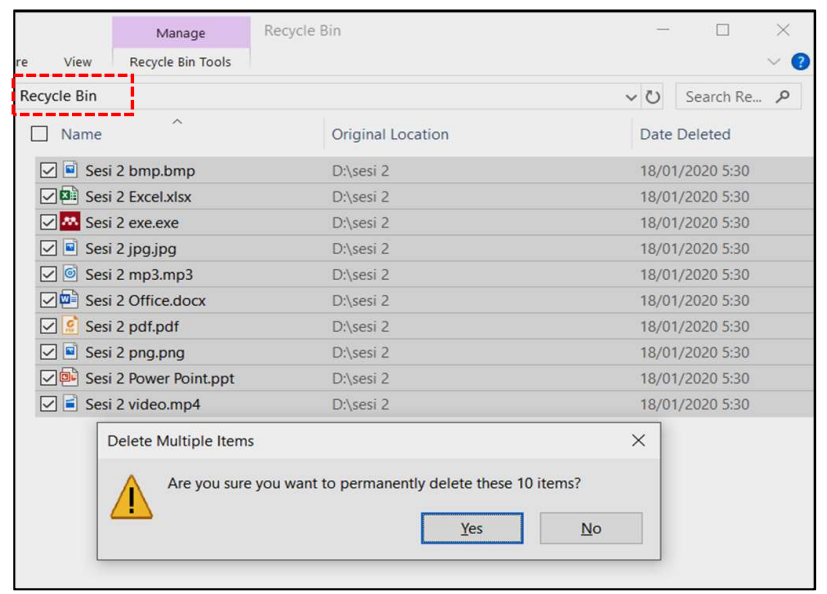

(b) Sesi 2 delete, delete recycle bin drive $\mathrm{E}$ :

Gambar 8. Metode penghapusan sesi 1 dan sesi 2

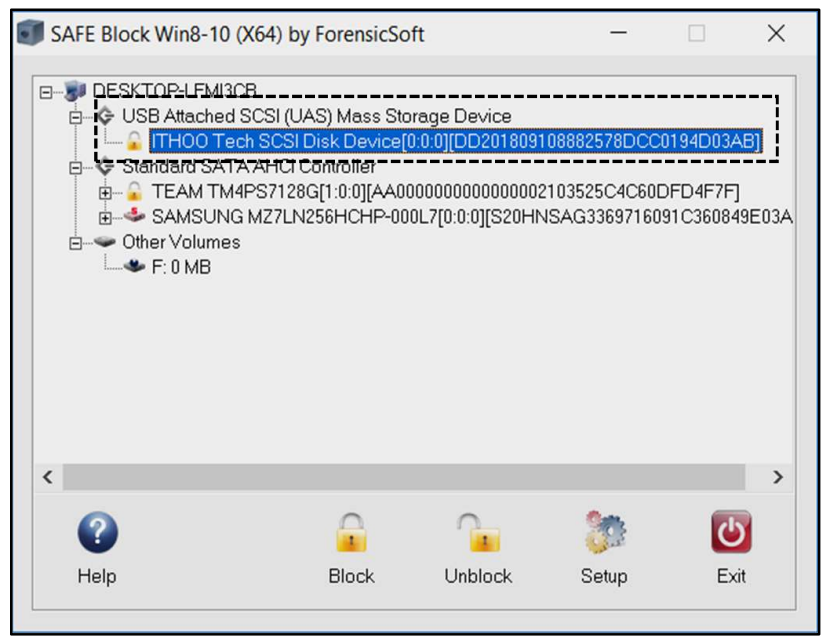

Gambar 9. Mengaktifkan write blocker pada konverter SSD NVMe to USB

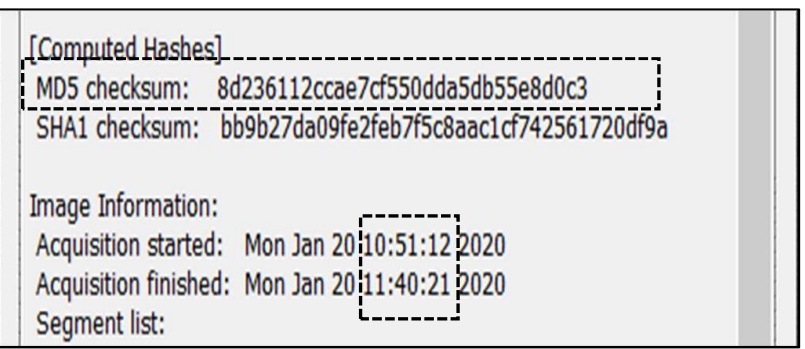

Gambar 10. Hasil laporan pembuatan image asli 
Hasil laporan pembuatan image pada Gambar 10 berupa nilai hash MD5 dengan kode yang unik yaitu $8 \mathrm{~d} 236112 \mathrm{ccae} 7 \mathrm{cf} 550 \mathrm{dda} 5 \mathrm{db} 55 \mathrm{e} 8 \mathrm{~d} 0 \mathrm{c} 3$, waktu yang dihabiskan untuk pembuatan image 49:09 menit. Proses ekstraksi barang bukti menggunakan salinan dari hasil pembuatan image dengan proses copy paste dan diverifikasi kembali nilai hash antara image asli dan image salinan. Berikut Gambar 11 nilai hash salinan image.

Berdasarkan Gambar 10 dan 11 proses copy paste image antara image asli dan image salinan mempunyai nilai yang sama.

\section{Eksaminasi}

Proses eksaminasi menggunakan salinan image yang sudah diverifikasi nilai hash dengan salinan asli. Tahapan eksaminasi berupa ekstraksi dan pemilahan berdasar verifikasi nilai hash bukti digital yang terhapus menggunakan tool forensics yang telah disiapkan yaitu Autopsy dan Recuva. Hasil eksaminasi SSD NVMe

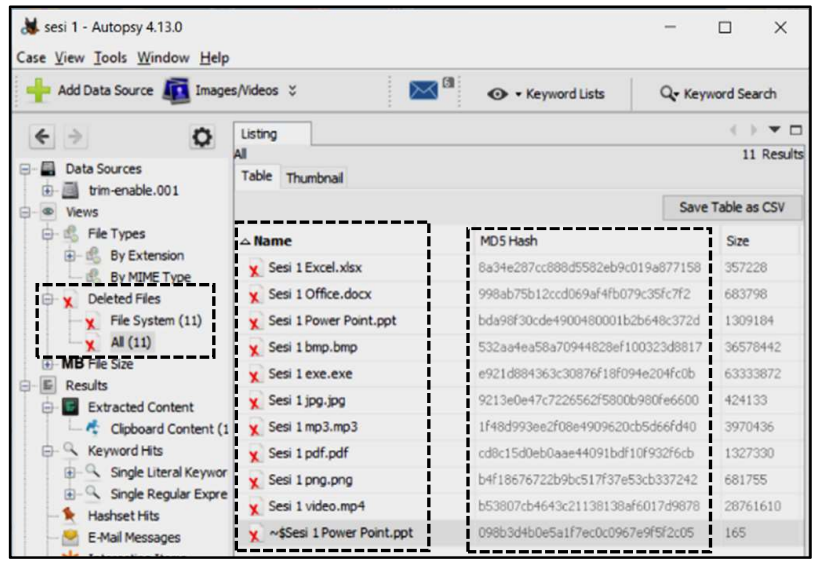

(a) Eksaminasi Sesi 1 menggunakan Autopsy sesi pertama Gambar 12 (a) dan sesi kedua Gambar 12 (b).

Hasil eksaminasi menggunakan Autopsy pada sesi pertama Gambar 12 (a) ditemukan 11 bukti digital dengan karakteristik nama file dan size sama tapi nilai hash berbeda, lokasi file berada di /img_trim-enable.001. Sedangkan pada Gambar 12 (b) sesi kedua ditemukan 29 bukti digital dengan karakteristik nama file berubah, size dan nilai hash sama dengan bukti digital asli, letak file berada di img trim-enable.001/\$RECYCLE.BIN. Proses eksaminasi menggunakan Recuva sesi pertama pada Gambar 13 (a) dan sesi kedua pada Gambar 13 (b).

\begin{tabular}{|c|c|c|c|c|}
\hline \multicolumn{2}{|l|}{$\square$ HashMyfiles } & \multirow[t]{2}{*}{-} & \multirow[t]{2}{*}{$\square$} & \multirow[t]{2}{*}{$\times$} \\
\hline File Edit View & Options Help & & & \\
\hline$\unlhd \square \star x$ & 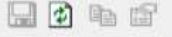 & 9 & & \\
\hline Filename & File Size & MD5 5 & & \\
\hline Whill trim-enable.001 & 128.034 .708 .480 & $8 \mathrm{~d} 236112$ ccae7cf55 & $5 \mathrm{db}$ & $10 \mathrm{c} 3$ \\
\hline
\end{tabular}

Gambar 11. Nilai hash salinan image

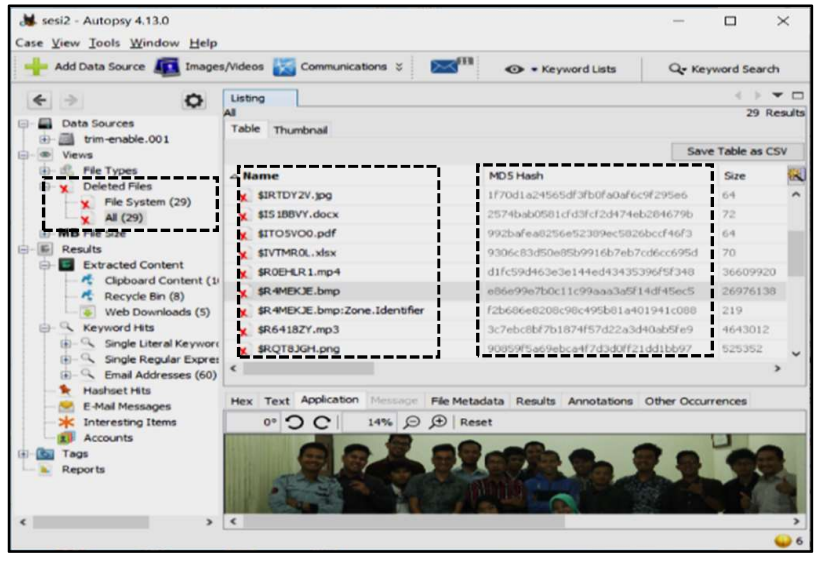

(b) Eksaminasi Sesi 2

Gambar 12. Eksaminasi menggunakan tool Autopsy

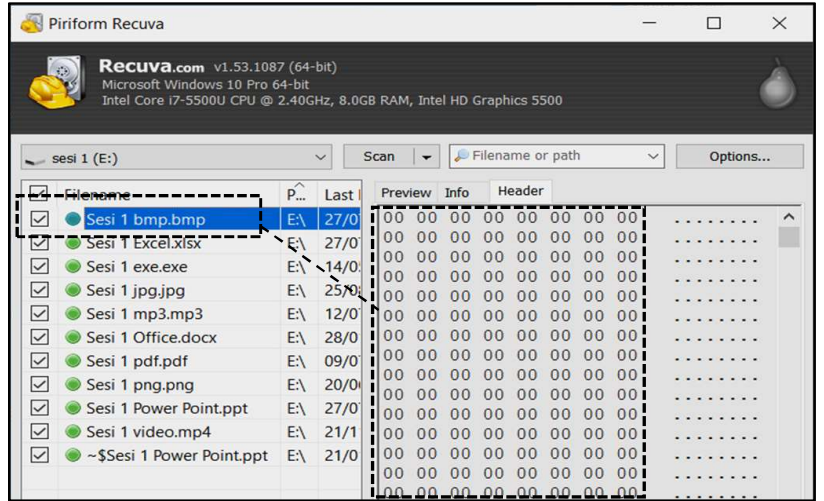

(a) Eksaminasi Sesi 1

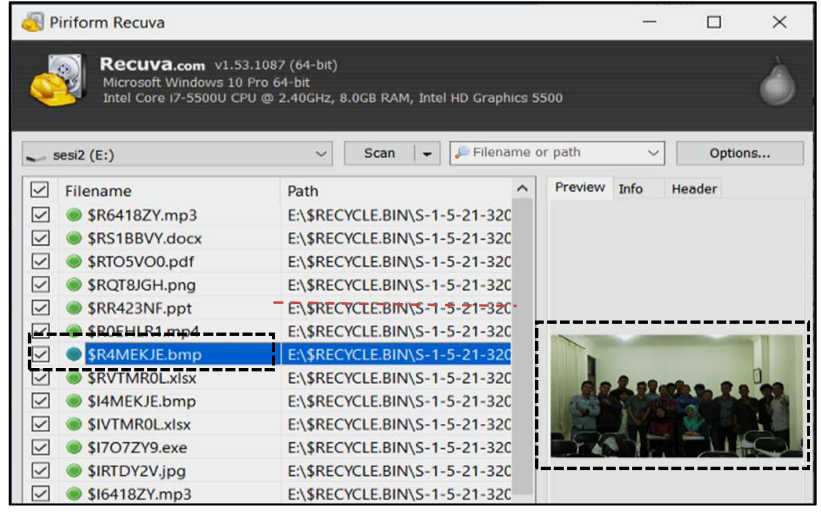

(b) Eksaminasi Sesi 2

Gambar 13. Eksaminasi menggunakan tool Recuva 
Hasil eksaminasi menggunakan Recuva pada sesi pertama Gambar 13 (b) ditemukan 11 file dengan karakteristik nama file sama, size sama tapi nilai hash berbeda, lokasi file berada di E: \. Sedangkan pada Gambar 13 (b) sesi kedua ditemukan 18 file dengan karakteristik nama file berubah, size dan nilai hash sama dengan bukti digital asli, letak file berada di E:I\$RECYCLE.BIN.

Berdasarkan hasil Gambar 12 dan Gambar 13 beberapa file dapat direstorasi menggunakan kedua tool tersebut. Rekapitulasi recovery file pada Tabel 2.

\section{Analisis}

Hasil recovery bukti digital dianalisis menggunakan tool forensics untuk pengecekan magic number pada header file disesuaikan dengan file signature berupa nilai hexadesimal dan validasi nilai hash [22], berikut Gambar 14 contoh analisis bukti digital menggunakan tool

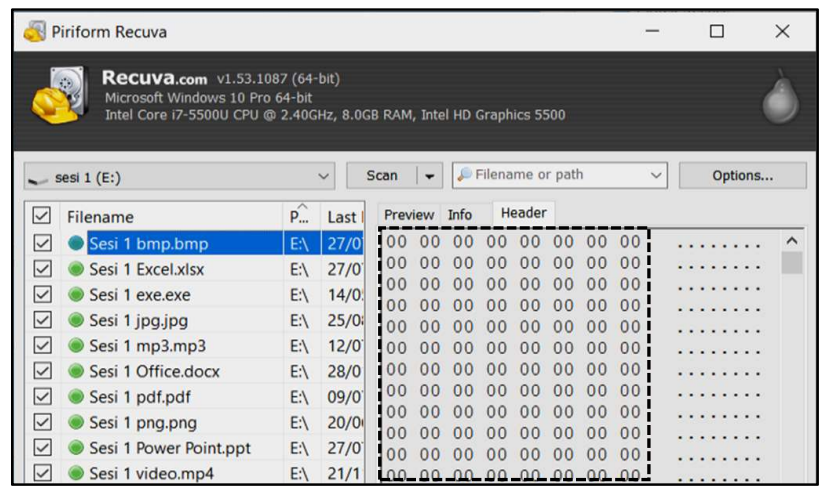

(a) Analisis Sesi 1
Recuva dengan pengecekan magic number pada sesi pertama dan sesi kedua.

Header pada Gambar 14 (a) tidak mempunyai nilai (zero) meskipun memiliki nilai size yang sama. Sedangkan pada header Gambar 14 (b) mempunyai nilai yang unik, 4 digit diawal header 42 4D menunjukkan magic number dengan extensi .bmp.

Selanjutnya tahapan analisis recovery bukti digital dengan validasi nilai hash dirangkum pada Tabel 3 untuk sesi pertama dan sesi kedua dengan menggunakan tool Autopsy.

TABEL II

HASIL REKAPITULASI RECOVERY AUTOPSY DAN RECUVA

\begin{tabular}{lcc}
\hline Sesi & Autopsy & Recuva \\
\hline Sesi 1 & 11 & 11 \\
Sesi 2 & 29 & 18 \\
\hline
\end{tabular}

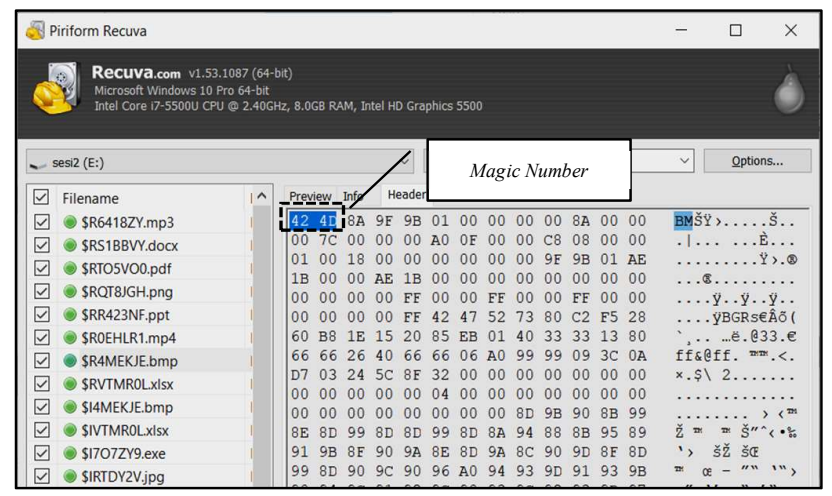

(b) Analisis Sesi 2

Gambar 14. Contoh analisis magic number pada header menggunakan tool Autopsy

TABEL III

VALIDASI NILAI HASH SESI 1 MENGGUNAKAN TOOL AUTOPSY

\begin{tabular}{|c|c|c|}
\hline Nama File & Hash MD5 & Validasi hash \\
\hline Sesi 1 bmp & 532aa4ea58a70944828ef100323d8817 & Tidak valid \\
\hline Sesi 1 xlsx & $8 \mathrm{a} 34 \mathrm{e} 287 \mathrm{cc} 888 \mathrm{~d} 5582 \mathrm{eb} 9 \mathrm{c} 019 \mathrm{a} 877158$ & Tidak valid \\
\hline Sesi 1 exe & e921d884363c30876f18f094e204fc0b & Tidak valid \\
\hline Sesi 1 jpg & $9213 \mathrm{e} 0 \mathrm{e} 47 \mathrm{c} 7226562 \mathrm{f} 5800 \mathrm{~b} 980 \mathrm{fe} 6600$ & Tidak valid \\
\hline Sesi $1 \mathrm{mp} 3$ & $1 \mathrm{f} 48 \mathrm{~d} 993 \mathrm{ee} 2 \mathrm{f} 08 \mathrm{e} 4909620 \mathrm{cb} 5 \mathrm{~d} 66 \mathrm{fd} 40$ & Tidak valid \\
\hline Sesi 1 docx & $998 \mathrm{ab} 75 \mathrm{~b} 12 \mathrm{ccd} 069 \mathrm{af} 4 \mathrm{fb} 079 \mathrm{c} 35 \mathrm{fc} 7 \mathrm{f} 2$ & Tidak valid \\
\hline Sesi 1 pdf & cd8c15d0eb0aae44091bdf10f932f6cb & Tidak valid \\
\hline Sesi 1 png & b4f18676722b9bc517f37e53cb337242 & Tidak valid \\
\hline Sesi $1 \mathrm{ppt}$ & bda98f30cde4900480001b2b648c372d & Tidak valid \\
\hline Sesi $1 \mathrm{mp} 4$ & b53807cb4643c21138138af6017d9878 & Tidak valid \\
\hline Sesi 2 bmp & e86e99e7b0c11c99aaa3a5f14df45ec5 & Valid \\
\hline Sesi 2 xlsx & $77 \mathrm{ac} 2 \mathrm{f} 423 \mathrm{a} 09 \mathrm{ef} 051100 \mathrm{e} 4 \mathrm{fe} 411 \mathrm{f} 9279$ & Valid \\
\hline Sesi 2 exe & e502f644456067d08942faecf5d4169a & Tidak valid \\
\hline Sesi 2 jpg & 400277f9a8290c47def497cfa8ee382c & Valid \\
\hline Sesi $2 \mathrm{mp} 3$ & $3 \mathrm{c} 7 \mathrm{ebc} 8 \mathrm{bf} 7 \mathrm{~b} 1874 \mathrm{f} 57 \mathrm{~d} 22 \mathrm{a} 3 \mathrm{~d} 40 \mathrm{ab} 5 \mathrm{fe} 9$ & Valid \\
\hline Sesi 2 docx & aa125f3e35214c72e3a87a11e3d4903f & Valid \\
\hline Sesi 2 pdf & 0a569b127c7de6bea02cf6e87e41c5f2 & Valid \\
\hline Sesi 2 png & 90859f5a69ebca4f7d3d0ff21dd1bb97 & Valid \\
\hline Sesi 2 ppt & $3352425 \mathrm{c} 3 \mathrm{dd} 400$ faca 160 feeeaf50210 & Valid \\
\hline Sesi 2 mp4 & d1fc59d463e3e144ed43435396f5f348 & Valid \\
\hline
\end{tabular}


Hasil analisis tool Autopsy sesi pertama dengan mencocokkan nilai hash Tabel 1 dan Tabel 3 tidak ditemukan bukti digital yang cocok dengan bukti digital asli. Sedangkan pada Sesi kedua ditemukan 9 dari 10 bukti digital dinyatakan sama nilai hash dengan bukti digital asli dan 1 bukti digital yang tidak sama nilai hash dengan ekstensi .exe.

Tahapan selanjutnya analisis recovery bukti digital yang ditemukan dengan mencocokkan nilai hash Tabel 1 dengan Tabel 4 untuk sesi pertama dan sesi kedua dengan menggunakan tool Recuva.

Hasil analisis tool Recuva sesi pertama pada Tabel 4 tidak ditemukan bukti digital yang cocok dengan bukti digital asli. Sedangkan sesi kedua ditemukan 8 dari 10 bukti digital mempunyai nilai hash yang sama dengan bukti digital asli, bukti digital tidak dapat ditemukan berupa satu file dengan ekstensi exe dan satu file ekstensi jpg.

Peneliti merangkum seluruh hasil penelitian pada Tabel 5 sebagai perbandingan tools forensics untuk recovery bukti digital pada SSD NVMe dengan metode penghapusan shift delete dan delete, delete recycle bin.

\section{PENUTUP}

Berdasarkan hasil analisis recovery bukti digital pada SSD NVMe menggunakan metode static forensics yang telah peneliti lakukan, fitur TRIM enable dengan metode penghapusan shift delete tidak dapat mengembalikan bukti digital yang sesuai nilai hash dengan bukti digital yang asli sedangkan metode penghapusan delete, delete recycle bin bukti digital dapat dikembalikan identik dengan nilai hash bukti digital yang asli. Prosantase dari 10 sampel bukti digital yang dapat dikembalikan dengan metode penghapusan delete, delete recycle bin menggunakan tool Autopsy sebesar $90 \%$ dan $10 \%$ nilai hash bukti digital tidak valid, sedangkan tool Recuva $80 \%$ bukti digital berhasil dikembalikan dan $20 \%$ tidak berhasil dikembalikan. Dapat disimpulkan hasil recovery penghapusan delete, delete recycle bin pada SSD NVME TRIM enable dapat dijadikan bukti digital yang sah menurut hukum. Pada penelitian berikutnya dapat dilanjutkan dengan menggunakan metode yang berbeda yaitu live forensics dan penggunaan tools forensics yang berbeda.

TABEL IV

VALIDASI NILAI HASH SESI 1 MENGGUNAKAN TOOL RECUVA

\begin{tabular}{lll}
\hline Nama File & Hash MD5 & Validasi hash \\
\hline Sesi 1 bmp & 532aa4ea58a70944828ef100323d8817 & Tidak valid \\
Sesi 1 xlsx & 8a34e287cc888d5582eb9c019a877158 & Tidak valid \\
Sesi 1 exe & e921d884363c30876f18f094e204fc0b & Tidak valid \\
Sesi 1 jpg & 9213e0e47c7226562f5800b980fe6600 & Tidak valid \\
Sesi 1 mp3 & 1f48d993ee2f08e4909620cb5d66fd40 & Tidak valid \\
Sesi 1 docx & 998ab75b12ccd069af4fb079c35fc7f2 & Tidak valid \\
Sesi 1 pdf & cd8c15d0eb0aae44091bdf10f932f6cb & Tidak valid \\
Sesi 1 png & b4f18676722b9bc517f37e53cb337242 & Tidak valid \\
Sesi 1 ppt & bda98f30cde4900480001b2b648c372d & Tidak valid \\
Sesi 1 mp4 & b53807cb4643c21138138af6017d9878 & Tidak valid \\
\$R4MEKJE.bmp & e86e99e7b0c11c99aaa3a5f14df45ec5 & Valid \\
\$RVTMR0L.xlsx & 77ac2f423a09ef051100e4fe411f9279 & Valid \\
(extensi exe) & - & Tidak ditemukan \\
(extensi jpg) & - & Tidak ditemukan \\
\$R6418ZY.mp3 & 3c7ebc8bf7b1874f57d22a3d40ab5fe9 & Valid \\
\$RS1BBVY.docx & aa125f3e35214c72e3a87a11e3d4903f & Valid \\
\$RTO5VO0.pdf & 0a569b127c7de6bea02cf6e87e41c5f2 & Valid \\
\$RQT8JGH.png & 90859f5a69ebca4f7d3d0ff21dd1bb97 & Valid \\
\$RR423NF.ppt & 3352425c3dd400faca160feeeaf50210 & Valid \\
\$R0EHLR1.mp4 & d1fc59d463e3e144ed43435396f5f348 & Valid \\
\hline
\end{tabular}

TABEL V

PERBANDINGAN RECOVERY TOOL FORENSICS

\begin{tabular}{lcccc}
\hline \multirow{2}{*}{ Nama File } & \multicolumn{2}{c}{ Autopsy } & \multicolumn{2}{c}{ Recuva } \\
\cline { 2 - 5 } & Sesi 1 & Sesi 2 & Sesi 1 & Sesi 2 \\
\hline Valid & 0 & 9 & 0 & 8 \\
Tidak valid & 10 & 1 & 10 & 0 \\
Tidak ditemukan & 0 & 0 & 0 & 2 \\
\hline
\end{tabular}




\section{DAFTAR PUSTAKA}

[1] R. Ruuhwan, I. Riadi, and Y. Prayudi, "Analisis Kelayakan Integrated Digital Forensics Investigation Framework Untuk Investigasi Smartphone," J. Buana Inform., vol. 7, no. 4, pp. 265-274, 2016.

[2] Eliasta Ketaren, "Cybercrime, Cyber Space, dan Cyber Law," Times, vol. 5, no. 2, pp. 35-42, 2016.

[3] B. J. Nikkel, "NVM Express Drives and Digital Forensics Introduction to NVM Express," No Starch Press, pp. 1-16, 2016.

[4] R. K. Chaurasia and P. Sharma, "Solid State Drive (SSD) Forensics Analysis: A New Challenge," Int. J. Sci. Res. Comput. Sci. Eng. Inf. Technol. C 2017 IJSRCSEIT, vol. 6, no. 2, pp. 1081-1085, 2017.

[5] M. Lawson, "Solid State Forensics," BSc Comput. Sci. with Secur. Forensics, p. 69, 2018.

[6] S. S. R. Marupudi, "Solid State Drive : New Challenge for Forensic Investigation,” p. 100, 2017.

[7] Z. Shah, A. N. Mahmood, and J. Slay, "Forensic potentials of solid state drives," Lect. Notes Inst. Comput. Sci. Soc. Telecommun. Eng. LNICST, vol. 153, no. September, pp. 113-126, 2015.

[8] I. Riadi and A. Hadi, "Analisis Bukti Digital SSD NVMe pada Sistem Operasi Proprietary Menggunakan Metode Static Forensics," CoreIt, vol. 3321, no. 2, pp. 1-8, 2019.

[9] A. Aldaej, M. G. Ahamad, and M. Y. Uddin, "Solid state drive data recovery in open source environment," in 2017 2nd International Conference on Anti-Cyber Crimes, ICACC 2017, 2017.

[10] R. A. Ramadhan, Y. Prayudi, and B. Sugiantoro, "Implementasi dan Analisis Forensika Digital Pada Fitur Trim Solid State Drive (SSD)," Teknomatika, vol. 9, no. 2, pp. 1-13, 2017.

[11] B. J. Raj and R. Hubbard, "Forensics Analysis of Solid State Drive ( SSD )," Proc. 2016 Univers. Technol. Manag. Conf., pp. 1-11, 2016.

[12] S. Sunardi, I. Riadi, and I. M. Nasrulloh, "Analisis
Forensik Solid State Drive (SSD) Menggunakan Framework Rapid Response," J. Teknol. Inf. dan Ilmu Komput., vol. 6, no. 5, p. 509, 2019.

[13] I. Riadi, R. Umar, and W. Sukarno, "Analisis Forensik Serangan Sql Injection Menggunakan Metode Statis Forensik," Pros. Interdiscip. Postgrad. Student Conf. 1st, vol. I, no. I, pp. 102-103, 2016.

[14] I. Riadi, "Forensic Investigation Technique on Android's Blackberry Messenger using NIST Framework," Int. J. Cyber-Security Digit. Forensics, vol. 6, no. 4, pp. 198205, 2017.

[15] A. R. Caesarano and I. Riadi, "Network Forensics for Detecting SQL Injection Attacks using NIST Method," Int. J. Cyber-Security Digit. Forensics, vol. 7, no. 4, pp. 436-443, 2018.

[16] A. Hadi and S. Riadi, Imam, "Forensik Bukti Digital Pada Solid State Drive (SSD) NVMe Menggunakan Metode National Institute of Standards and Technology (NIST)," SEMNASTEK 2019, pp. 551-558, 2019.

[17] Sunardi, I. Riadi, and A. Sugandi, "Forensic analysis of Docker Swarm cluster using GRR Rapid Response framework," Int. J. Adv. Comput. Sci. Appl., vol. 10, no. 2, pp. 459-466, 2019.

[18] I. Riadi, R. Umar, and A. Sugandi, "Web Forensic On Kubernetes Cluster Services Using Grr Rapid Response Framework," vol. 9, no. 01, pp. 3484-3488, 2020.

[19] A. Yudhana, I. Riadi, and I. Anshori, "Analisis Bukti Digital Facebook Messenger Menggunakan Metode Nist," It J. Res. Dev., vol. 3, no. 1, p. 13, 2018.

[20] L. S. Negara, J. Harsono, R. M. No, and J. Selatan, "Elektronik Pemerintahan Guna Mendukung EGovernment," 2016.

[21] S. Kandala, "Analyzing the Trimming Activity of SolidState Drives in Digital Forensics," 2019.

[22] R. Kadam, A. Saraf, D. Dave, and S. Faculty, "A Comprehensive Study On Linux Forensics," vol. 21, no. 14, pp. 12-21, 2019. 